\title{
EFEKTIFITAS PRODUKSI ASI PADA IBU POST PARTUM DENGAN MASSAGE ROLLING (PUNGGUNG)
}

\author{
Elvika Fit Ari Shanti \\ STIKes Jenderal A. Yani Yogyakarta, el vicha@yahoo.co.id
}

\section{INFO ARTIKEL}

\section{Riwayat Artikel:}

Diterima: 17-01-2018

Disetujui: 31-01-2018

\section{Kata Kunci:}

Massage Rolling, Produksi ASI

\section{ABSTRAK}

Abstrak: Produksi ASI yang kurang dan lambat keluar dapat menyebabkan ibu tidak memberikan ASI pada bayinya dengan cukup. Selain hormon prolaktin, proses laktasi juga bergantung pada hormon oksitosin, yang dilepas dari hipofise posterior sebagai reaksi terhadap penghisapan putting. Rolling massage salah satu terapi relaksasi yang bertujuan menstimulasi saraf pusat pada hipofisis posterior dan anterior sehingga dapat meningkatkan produksi ASI khususnya pada ibu post partum dan memberikan kenyamanan dan rileksasi setelah persalinan. Adapun tujuan penelitian adalah mengetahui efektifitas produksi ASI pada ibu post partum dengan massage rolling (punggung) di BPM Sri Sukeni Sleman. Metode penelitian ini adalah Quasi Experimental Design dengan rancangan penelitian two group post test design. Kelompok kontrol adalah ibu postpartum tanpa dipijat Massage roliing dan kelompok perlakuan adalah kelompok ibu postpartum yang dipijat masssage Roliing. Analisis data menggunakan uji independent $t$ test dan paired sample $t$ test. Hasil penelitian uji $t$ sampel menunjukkan bahwa ada perbedaan yang bermakna $(p=0.023<\infty)$ produksi ASI (berat badan bayi) antara kelompok kontrol ( 2687,07 \pm $160,155)$ dengan kelompok perlakuan $(2846,13 \pm 198,968)$. Perbedaan ini terlihat pada rerata berat badan bayi pada kelompok perlakuan lebih besar dibandingkan dengan kelompok. Massage rolling memengaruhi produksi ASI di BPM Sri Sukeni Sleman Tahun 2017.

\begin{abstract}
The inadequate, slow production of breast milk makes mothers unable to provide enough breast milk to their babies. Besides the prolactin hormone, the lactation process also depends on oxytocin hormone which is secreted from the posterior hypophysis as a reaction on nipple suckling. Rolling massage is one of the relaxation therapy which aims to stimulate the central nerve on posterior and anterior hypophysis, so the breast milk production can be increased, particularly in the postpartum mothers, and comfort and relaxation after childbirth can be provided. This research aims to investigate the effectiveness of breast milk production in the postpartum mothers with massage rolling (back) in Sri Sukeni Community Empowerment Agency, Sleman. The methodology in this research is Quasi-Experimental Design with two-group posttest design. The control group is postpartum mothers without massage rolling and the treatment group is postpartum mother treated with the massage rolling. Data analysis used the independent $t$-test and the paired sample $t$-test. The research shows the result that in samples of $t$-test, there is a meaningful difference $(p=0.023<\alpha)$ in breast milk production (weight of baby) between control group $(2,687.07 \pm 160.155)$ and treatment group $(2,846.13 \pm 198.968)$. This difference is shown in the average weight of baby in treatment group which is higher compared with the control group. Massage rolling affects breast milk production in Sri Sukeni Community Empowerment Agency, Sleman in 2017.
\end{abstract}




\section{A. PENDAhUluan}

Organisasi Kesehatan Dunia (WHO) merekomendasikan agar setiap bayi baru lahir mendapatkan ASI eksklusif selama enam bulan. Pemberian ASI Eksklusif selama enam bulan sudah dibuktikan secara ilmiah dapat memenuhi kebutuhan nutrisi bayi (Roesli, 2008) Salah satu alasan penyebab ketidakberhasilan pemberian ASI eksklusif ini adalah ibu kurang percaya diri bahwa ASI yang dimiliki dapat mencukupi kebutuhan nutrisi bayinya (Roesli, 2008). Hal ini terjadi karena ASI yang tidak keluar atau hanya keluar sedikit pada hari-hari pertama setelah melahirkan. Hasil Riskesdas (2013) menyatakan bahwa persentase proses bayi mulai mendapat ASI antara 1-6 jam sebesar 35,2\%, persentase proses bayi mulai mendapat ASI antara 7-23 jam sebesar 3,7\%, persentase proses bayi mulai mendapat ASI antara 24-47 jam sebesar 13,0\%, persentase proses bayi mulai mendapat ASI lebih dari 47 jam sebesar $13,7 \%$.

Dalam kondisi yang penuh kekhawatiran dan tidak percaya diri karena merasa ASI tidak cukup, ibu memerlukan bantuan dan dukungan untuk dapat mempertahankan produksi ASI. Dengan rasa tidak percaya diri dan kekhawatiran akan menyebabkan Terhambatnya pengeluaran hormon oksitosin. Hormon oksitosin berdampak pada pengeluaran hormon prolaktin sebagai stimulasi produksi ASI pada ibu selama menyusui (Amin, 2011)

Tindakan massage rolling punggung dapat memengaruhi hormone prolaktin yang berfungsi sebagai stimulus produksi ASI pada ibu selama menyusui. Tindakan Massage rolling (punggung) akan memberikan kenyamanan dan membuat rileks ibu karena massage dapat merangsang pengeluaran hormone endorphin serta dapat menstimulasi refleks oksitosin. Tehnik pemijatan pada titik tertentu dapat menghilangkan sumbatan dalam darah dan energy di dalam tubuh akan kembali lancar (Dalimartha, 2008). Punggung merupakan titik akupresur untuk memperlancar proses laktasi. Selain itu saraf pada payudara dipersyarafi oleh syaraf punggung atau dorsal yang menyebar disepanjang tulang belakang (Cooper, Bart, 2005). Penelitian oleh Mulyati (2009) Massase merupakan salah satu terapi pendukung yang efektif untuk mengurangi ketidaknyamanan fisik serta memperbaiki mood dan memberikan efek rileks pada ibu secara tidak langsung dapat menstimulasi hormon oksitosin yang dapat membantu proses kelancaran produksi ASI. Penelitian Desmawati (2008) didapatkan hasil bahwa ibu postpartum yang diberi intervensi kombinasi areola massage dengan rolling massage mempunyai peluang 5,146 kali untuk terjadi pengeluaran ASI kurang dari 12 jam postpartum)

\section{B. METODE PENELITIAN}

Metode penelitian ini adalah Quasi Experimental Design dengan rancangan penelitian two group post test design. Kelompok kontrol adalah ibu postpartum Untuk kelompok kontrol peneliti akan menimbang berat badan bayi selama 3-4 hari dengan datang ke rumah responden, dan pada hari ke-5 baru dilakukan pijat Massage Rolling kepada responden. Dan pada ibu post partum yang tanpa dipijat Massage roliing dan kelompok perlakuan adalah kelompok ibu postpartum yang dipijat masssage Roliing. Analisis data menggunakan uji independent $t$ test dan paired sample t test.

\section{HASIL}

Hasil dari karakteristik responden dari BPM Sri. Sukeni Karaketeristik responden berdasarkan umur pendidikan dan pekerjaan di BPM Sri Sukeni

\section{Karakteristik Responden}

TABEL 1

Distribusi Frekuensi Karakteristik Responden

\begin{tabular}{llcccc}
\hline & & \multicolumn{4}{c}{ Kelompok } \\
\cline { 3 - 6 } o & Variabel & $\begin{array}{c}\text { Perl } \\
\text { akua } \\
\text { n }\end{array}$ & $\begin{array}{c}\text { Perse } \\
\text { ntase } \\
\text { (\%) }\end{array}$ & $\begin{array}{c}\text { Ko } \\
\text { ntr } \\
\text { ol }\end{array}$ & $\begin{array}{c}\text { Persenta } \\
\text { se (\%) }\end{array}$ \\
\hline 1. & Umur & & & & \\
& $\quad$ 20 Tahun & 0 & 0 & 0 & 0 \\
& 20-35 Tahun & 15 & 100 & 12 & 80 \\
& >35 Tahun & 0 & 0 & 3 & 20 \\
2. & Pendidikan & & & & \\
& SD & 0 & 0 & 0 & 0 \\
& SMP & 6 & 40 & 7 & 46,6 \\
& SMA & 6 & 40 & 8 & 53,3 \\
& D-1 & 1 & 6,66 & 0 & 0 \\
D-3 & 2 & 13,3 & 0 & 0 \\
3. & & & & \\
& IRT & 8 & 53,33 & 10 & 66,66 \\
Buruh & 2 & 13,33 & 1 & 6,666 \\
Swasta & 4 & 26,66 & 2 & 13,33 \\
PNS & 1 & 6,666 & 2 & 13,33 \\
\hline
\end{tabular}

Berdasarkan tabel 1, dapat diketahui bahwa karakteristik responden berdasarkan umur pada kelompok kontrol dan perlakuan sebagian besar adalah usia reproduksi 20-35 tahun kelompok kontrol 80\% dan kelompok perlakuan $100 \%$. 


\section{Analisis Univariat}

Gambaran Produksi ASI Hari ke-4 pada kelompok kontrol

TABEL 2

Distribusi Frekuensi Produksi ASI Hari ke-4 Kelompok kontrol

\begin{tabular}{cccc}
\hline No & $\begin{array}{c}\text { Produksi ASI } \\
\text { (Berat Badan } \\
\text { Bayi) }\end{array}$ & Frekuensi & $\begin{array}{c}\text { Persentase } \\
(\%)\end{array}$ \\
\hline 1 & Cukup & 15 & 100 \\
2 & Kurang & 0 & 0 \\
\hline & Jumlah & 15 & 100 \\
\hline
\end{tabular}

Berdasarkan tabel 2, dapat diketahui bahwa produksi ASI pada kelompok kontrol semua dalam kategori cukup 15 (100\%).

Gambaran Produksi ASI Hari ke-4 pada kelompok perlakuan

TABEL 3

Distribusi Frekuensi Produksi ASI Hari ke-4 Kelompok Perlakuan (Diberikan Massage Rolling)

\begin{tabular}{cccc}
\hline No & $\begin{array}{c}\text { Produksi ASI } \\
\text { (Berat Badan } \\
\text { Bayi) }\end{array}$ & Frekuensi & Presentase (\%) \\
\hline 1 & Cukup & 15 & 100 \\
2 & Kurang & 0 & 0 \\
\hline & Jumlah & 15 & 100 \\
\hline
\end{tabular}

Berdasarkan tabel 3, dapat diketahui bahwa produksi ASI pada kelompok perlakuan semua dalam kategori cukup 15 (100\%).

\section{Analisis Bivariat}

\section{Hasil Uji Prasyarat Parametrik}

Uji normalitas pada penelitian ini, dilakukan dengan menggunakan uji Shapiro-Wilk. Adapun kriteria keputusan, yaitu bila nilai Sig atau $p$-value lebih besar dari taraf signifikansi $\propto>0.05$ maka data terdistribusi normal dan sebaliknya bila nilai Sig atau $p$-value lebih kecil dari taraf signifikansi $\propto$ $\leq 0.05$ maka data tidak terdistribusi normal.

TABEL 4

Hasil uji Normalitas Data

\begin{tabular}{ccccc}
\hline Variabel & Kelompok & $\mathrm{N}$ & p-value & Kesimpulan \\
\hline BB Bayi & Kontrol & $\mathbf{1 5}$ & $\mathbf{0 , 1 1 9}$ & Normal \\
& Perlakuan & $\mathbf{1 5}$ & $\mathbf{0 , 0 9 3}$ & Normal \\
\hline
\end{tabular}

\section{Keterangan:}

Jika p-value $<0.05$ berarti tidak berdistribusi normal, $p$-value $>=0.05$ berarti data terdistribusi normal. Berdasarkan tabel 4 diperoleh data berat badan bayi untuk masing-masing kelompok menunjukkan nilai p-value semuanya lebih besar dari taraf signifikansi $\propto=0.05$. Data yang dihasilkan telah memenuhi uji prasyarat parametrik, yaitu data terbukti terdistribusi normal, selanjutnya data siap dianalisis lebih lanjut dengan uji statistik parametrik guna membuktikan hipotesis penelitian yang telah diajukan.

\section{Hasil uji perbedaan produksi ASI antara kelompok kontrol dan perlakuan}

Pada hasil uji perbandingan kelompok kontrol dengan perlakuan pada data berat badan bayi (gram) menggunakan uji $\mathrm{t}$ sampel bebas (independent sample $t$ test) ditunjukkan secara ringkas pada tabel di bawah in

\section{TABEL 5}

Hasil Uji Perbedaan Produksi ASI antara kelompok kontrol dan perlakuan

\begin{tabular}{cccc}
\hline & Kelompok & Kelompok & \\
Variabel & Kontrol & Perlakuan & p-value \\
& Rerata \pm & Rerata \pm & \\
& stan.dev & stan.dev & \\
Berat Badan & $2687,07 \pm$ & $2846,13 \pm$ & 0.023 \\
Bayi & 160,155 & 198,968 & $<\propto$ \\
\hline
\end{tabular}

Keterangan:

Jika $p$-value $<0.05$ berarti ada perbedaan yang bermakna daan, jika $p$-value $>=0.05$ berarti tidak ada perbedaan yang bermakna.

Pada Tabel 5 berdasarkan hasil uji t sampel menunjukkan bahwa ada perbedaan yang bermakna $(\mathrm{p}=0.011<\propto)$ produksi ASI (berat badan bayi) antara kelompok kontrol $(2687,07 \pm 160,155)$ dengan kelompok perlakuan $(2846,13 \pm 198,968)$ Perbedaan ini terlihat pada rerata berat badan bayi pada kelompok perlakuan lebih besar dibandingkan dengan kelompok kontrol.

\section{Hasil Uji perbedaan produksi ASI sebelum} dan sesudah dilakukan Massage Rollingdre

Pada hasil uji perbedaan produksi ASI sebelum dan sesudah dilakukan Massage Rolling digambarkan dengan data berat badan (gram) menggunakan uji paired sample t test ditunjukkan secara ringkas pada tabel di bawah ini.

TABEL 6

Hasil Uji Perbedaan Produksi ASI sebelum dan sesudah dilakukan Massage Rolling

\begin{tabular}{|c|c|c|c|c|}
\hline \multirow[b]{2}{*}{ Variabel } & \multicolumn{4}{|c|}{ CI 95\% } \\
\hline & $\begin{array}{c}\text { SE } \\
\text { Mean }\end{array}$ & Lower & Upper & $\begin{array}{c}\mathrm{p}- \\
\text { value }\end{array}$ \\
\hline $\begin{array}{l}\text { Pre-post berat } \\
\text { badan bayi } \\
\text { (Perlakuan) }\end{array}$ & 5,825 & $\begin{array}{l}232,84 \\
\mathrm{O}\end{array}$ & 257,827 & $\begin{array}{l}0.00< \\
\propto\end{array}$ \\
\hline $\begin{array}{l}\text { Pre-post berat } \\
\text { badan bayi } \\
\text { (Kontrol) }\end{array}$ & 4,362 & 228,78 & $\begin{array}{l}247,48 \\
9\end{array}$ & $\begin{array}{l}0.000 \\
<\propto\end{array}$ \\
\hline
\end{tabular}

\section{Keterangan:}

Jika p-value $<0.05$ berarti ada perbedaan yang bermakna dan jika $p$-value $>=0.05$ berarti tidak ada perbedaan yang bermakna. 
Pada Tabel 6 berdasarkan hasil uji $t$ sampel menunjukkan bahwa ada perbedaan yang bermakna $(\mathrm{p}=0.000<\propto)$ produksi ASI (berat badan bayi) sebelum dan sesudah dilakukan Massage Rolling. Pada kelompok kontrol juga menunjukkan ada perbedaan yang bermakna $(\mathrm{p}=0.000<\propto)$ produksi ASI pada hari pertama dan hari ke-empat

\section{PEMBAHASAN}

\section{Gambaran karakteristik responden}

Dalam penelitian ini, karakteristik ibu postpartum yang menjadi variabel adalah umur, pendidikan, dan pekerjaan. Karakteristik responden berdasarkan umur pada kelompok kontrol dan perlakuan sebagian besar adalah usia reproduksi 20-35 tahun. Karakteristik responden berdasarkan pendidikan pada kelompok kontrol dan perlakuan sama yaitu SMA, Sedangkan pada berdasarkan pekerjaan pada kelompok kontrol sebagian besar adalah IRT dan kelompok perlakuan sebagian besar adalah swasta.

\section{Gambaran Produksi ASI Hari ke-4 pada kelompok kontrol dan perlakuan}

Produksi ASI cukup atau tidak bisa dilihat dari berbagai indikator, seperti : perubahan berat badan, jumlah BAK, dan Jumlah BAB. Tanda yang paling dapat dipercaya adalah pertambahan berat badan bayi (UNICEF, 2011).

Hasil penelitian ini menunjukkan bahwa pada kelompok kontrol dan kelompok perlakuan produksi ASI semua ibu dalam kategori cukup 15 (100\%) kelompok kontrol dan 15 (100\%) kelompok perlakuan. Hal ini disebabkan karena dari 30 bayi pada hari ke-4 tidak ada yang kehilangan berat badan lebih dari 8\% berat badan lahir.

Bayi baru lahir akan kehilangan sedikit berat badan pada beberapa hari pertama kehidupanya. Hal ini terjadi karena adanya proses adaptasi bayi dari dalam kandungan ke luar kandungan dan biasa disebut sebagai masa transisi. Bayi baru lahir dikatakan tidak cukup ASI atau produksi ASI-nya kurang jika bayi ditimbang pada hari ke-3 dan 4 kehilangan $8 \%$ dari berat badan lahir. Bayi dengan keadaan seperti ini membutuhkan kecukupan ASI yang lebih dan ibu membutuhkan support untuk menyusui bayinya (UNICEF, 2011).

Bila dilihat dari hasil penelitian bahwa semua bayi tidak ada yang mengalami penurunan sebanyak $8 \%$ maka dapat disimpulkan bahwa bayi mendapatkan cukup ASI dan produksi ASI dikatakan lancar jika penurunan berat badan bayi yang cukup mendapatkan nutrisi hanya terjadi sampai hari ke 3 setelah lahir dan akan terjadi peningkatan rata rata 200 gr per minggu.

\section{Hasil uji perbedaan produksi ASI antara kelompok kontrol dan perlakuan}

Berdasarkan hasil uji $t$ sampel menunjukkan bahwa ada perbedaan yang bermakna $(\mathrm{p}=0.023<\propto)$ produksi ASI (berat badan bayi) antara kelompok kontrol $(2687,07 \pm 160,155)$ dengan kelompok perlakuan $(2846,13 \pm 198,968)$. Perbedaan ini terlihat pada rerata berat badan bayi pada kelompok perlakuan lebih besar dibandingkan dengan kelompok kontrol.

Faktor yang menyebabkan hormon oksitosin dikeluarkan adalah rasa tenang, nyaman, ibu tidak stres, ibu senang dengan bayi dan keadaannya. Untuk itu hormon oksitosin juga disebut sebagai hormon cinta (UNICEF, 2011).

Hasil penelitian ini juga sesuai dengan Mulyati (2009) masase/pijat merupakan salah satu terapi pendukung yang efektif untuk mengurangi ketidaknyamanan fisik serta memperbaiki gangguan mood. Pengurangan ketidaknyamanan pada ibu menyusui akan membantu lancarnya pengurangan ASI. Terjadinya peningkatan produksi ASI pada kelompok perlakuan dapat memberikan efek rileks pada ibu yang secara tidak langsung dapat menstimulasi hormon oksitosin yang dapat membantu proses kelancaran produksi ASI.

Selain memperlancar ASI Massage Rolling juga memberikan kenyamanan pada ibu nifas, mengurangi bengkak (engorgement), mengurangi sumbatan ASI, merangsang pelepasan hormon oksitosin, mempertahankan produksi ASI ketika ibu dan bayi sakit (Wulandari, 2014).

\section{Hasil Uji perbedaan produksi ASI sebelum dan sesudah dilakukan Massage Rolling}

Berdasarkan hasil uji $t$ sampel menunjukkan bahwa ada perbedaan yang bermakna $(\mathrm{p}=0.023<\propto)$ produksi ASI (berat badan bayi) sebelum dan sesudah dilakukan Massage Rolling. Sesuai teori bahwa pemijatan merupakan salah satu terapi pendukung yang efektif untuk mengurangi ketidaknyamanan fisik serta memperbaiki gangguan mood. Pengurangan ketidaknyamanan pada ibu menyusui akan membantu lancarnya pengeluaran ASI (Ritchmond dan Aprillia, 2011). Penatalaksanaan non farmakologi untuk meningkatkan produksi ASI dengan metode Massage Rolling merupakan salah satu alternatif untuk meningkatkan kenyamanan dan relaksasi ibu postpartum selama masa menyusui sehingga dapat meningkatkan volume ASI. Metode Massage Rolling memberikan stimulasi refleks pembentukan ASI (prolaktin refleks) dan pengeluaran ASI (let down reflex) (Pamuji dkk, 2014)

Hasil penelitian ini sesuai dengan penelitian yang dilakukan oleh Bowel (2011) yang bertujuan untuk melihat efektifitas pijat payudara terhadap produksi ASI yang dilakukan terhadap 30 ibu yang 
masing-masing dibagi dalam kelompok kontrol dan kelompok perlakuan. Di mana dalam penelitiannya ini para bayi dari ibu pada kedua kelompok terlebih dahulu ditimbang sebelum dan setelah menyusui untuk mengetahui jumlah susu yang tertelan. Dari hasil penelitiannya menunjukkan bahwa bayi dari kelompok yang dilakukan pijat payudara mengonsumsi rata-rata 22,3 gr ASI setiap kali menyusui dibandingkan bayi yang berada pada kelompok yang tidak dilakukan pijat payudara, dan berdasarkan perbandingan terhadap total harian bayi yang berada pada kelompok perlakuan ratarara mengonsumsi 4,5 ons ASI lebih banyak dibanding bayi pada kelompok kontrol.

Hasil penelitian Kurniatika (2013) menunjukkan bahwa ada peningkatan berat badan bayi setelah diberi ASI selama satu bulan. Secara teori, beberapa hari setelah lahir berat badan bayi akan turun lima hingga sepuluh persen dari berat badan bayi saat lahir. Hal ini normal terjadi karena bayi kehilangan cairan saat dilahirkan dan asupan ASI pada hari-hari pertama belum maksimal. Karena itulah, berat badan bayi tidak dapat segera kembali seperti saat dilahirkan, atau naik dengan cepat. Berat badan bayi akan meningkat dalam 14 hari, seiring dengan kemahirannya menyusu dan mendapatkan ASI (Ibu dan Balita, 2013).

\section{E. SIMPULAN}

Berdasarkan hasil analisa data dan pembahasan diperoleh kesimpulan bahwa rerata berat badan bayi pada kelompok perlakuan lebih besar dibandingkan dengan kelompok sehingga Massage rolling memengaruhi produksi ASI di BPM Sri Sukeni Sleman Tahun 2017. Hal ini dibuktikan dengan hasil penelitian uji t sampel menunjukkan bahwa ada perbedaan yang bermakna $(p=0.023<\alpha)$ produksi ASI (berat badan bayi) antara kelompok kontrol ( $2687,07 \pm 160,155)$ dengan kelompok perlakuan $(2846,13 \pm 198,968)$.

\section{DAFTAR RUJUKAN}

1. Amin M, Rehana, Jaya H. (2011). Efektifitas Massage Rolling (punggung) terhadap produksi ASI pada Ibu Post SEctio Caesaria di RS Muhammadiyah Palembang. Jurnal Keperawatan

2. Asiyah, N., Wigati, A. 2015. Minyak Aromaterapi Sebagai Media Peningkatan Produksi ASI. JIKK Vol. 6 No. 2

3. Astuti, P.H., (2013). Buku Ajar ASuhan Kehamilan Ibu 1. Rahma Press : Yogyakarta

4. Balitbang Kemenkes RI. 2013. Riset Kesehatan Dasar; RISKESDAS.Jakarta: Balitbang Kemenkes RI
5. Biancucuzzo, M. (2003). Breasfeeding The Newborn: Clinical Strategies For Nurses. St.Louis: Mosby

6. Depkes RI (2007). Manajemen Laktasi,Jakarta: EGC

7. Desmawati. (2013) Penentu Kecepatan Pengeluaran Air Susu Ibu (ASI) setelah Secsio Caesaria. Jurnal Kesehatan Masyarakat Nasional. Vol :7. No. 8(360-364)

8. Dinkes DIY. 2012. Profil Kesehatan Provinsi DIY tahun 2011. Dinas Kesehatan DIY

9. Hamranani, S. 2010, Pengaruh pijat oksitosin terhadap involusi uterus pada ibu post partum yang mengalami persalinan lama di rumah sakit wilayah Kabupaten Klaten. Tesis UI

10. Nursalam, 2003.Konsep dan Penerapan Metodologi Penelitian Ilmu Keperawatan. Jakarta : Salemba Medika

11. Pamuji., Supriyana., Rahayu. (2014) Pengaruh Kombinasi Metode Massage Rolling dan Endorphine Terhadap Kadar Hormon Prolaktin dan Volume ASI (Studi Pada Ibu Postpartum Di Griya Hamil Sehat Mejasem Kabupaten Tegal). Vol. 5. No. 1. BHAMADA, JITK,.

12. Roesli, U (2008). Inisiasi Menyusu Dini Plus ASI Eksklusif. Jakarta : Pustaka Bunda

13. (2009). ASI Eksklusif. Jakarta : Pustaka Bunda

14. Santoso. (2005). Mengolah Data Statistik Secara Profesional. Jakarta : Elex Media Komputindo (Gramedia)

15. Tikawati, K, F. (2015). Penerapan Tindakan Massage Rolling Punggung Terhadap Peningkatan Produksi ASI Pada Asuhan Keperawatan Ny. T Post Sectio Caesaria Di Ruang Mawar 1 Rumah Sakit Umum Dr. Moewardi Surakarta. KTI. Stikes Kusuma Husada. Surakarta.

16. Suhermi, Dkk. (2008). Perawatan Masa Nifas.Yogyakarta: Fitramaya.

17. UNICEF. (2011). Pelatihan Konseling Menyusui. World Health Organization. 